\title{
KONTRIBUSI ISLAM TERHADAP MASA DEPAN PERADABAN DI ASIA TENGGARA
}

\author{
Bahrul Hayat \\ Program Pascasarjana Fakultas Psikologi Universitas Indonesia \\ Jl. Salemba Raya No. 4 Jakarta, 10430 \\ e-mail: bhayat@rad.net.id, sekjen@kemenag.go.id
}

\begin{abstract}
Abstrak: Beberapa ahli memperkirakan ada sekitar 1,6 miliar orang Muslim di dunia, di mana 62.1 \% dari mereka hidup di kawasan Asia. Hanya $15 \%$ adalah Muslim Arab, sedangkan hampir sepertiga hidup di Asia Tenggara. Islam di Asia Tenggara relatif lebih moderat dibandingkan Islam di Timur Tengah. Sifat moderasi ini merupakan bagian yang tidak terpisah dari perkembangan Islam di Asia Tenggara. Islam sampai ke Asia Tenggara melalui jalur perdagangan dan tidak melalui penaklukan militer seperti yang banyak terjadi di dunia Arab, Asia Selatan dan Timur Tengah. Islam juga diwarnai pada paham animisme, Hindu, dan tradisi Buddha di Indonesia, yang memberikan ciri sinkritisme. Islam baru tersebar di Asia Tenggara pada akhir abad ke-17. Kebangkitan Islam telah mengubah wajah politik Islam di Asia Tenggara. Memang benar bahwa Islam Asia Tenggara termasuk di antara Islam yang sangat minimal corak kearabannya yang diakibatkan oleh proses islamisasi yang pada umumnya berlangsung damai.
\end{abstract}

\begin{abstract}
Abctract: The Contribution of Islam towards Southeast Asian Future Civilization. By some estimates there are approximately 1.6 billion Muslims in the world, of which $62.1 \%$ live in Asia. Only 15\% of Muslims are Arab, while almost one third live in Southeast Asia. Islam in Southeast Asia is relatively more moderate in character than in much of the Middle East. This moderation stems in part from the way Islam evolved in Southeast Asia. Islam came to Southeast Asia with traders rather than through military conquest as it did in much of South Asia and the Arab Middle East. Islam also was overlaid on animist, Hindu, and Buddhist traditions in Indonesia, which are said to give it a more syncretic aspect. Islam spread throughout much of Southeast Asia by the end of the seventeenth century. The Islamic revival is changing the face of political Islam in Southeast Asia. It is true that Southeast Asian Islam is among the least Arabicized forms of Islam, largely as a result of a process of Islamization that was generally peaceful.
\end{abstract}

Kata Kunci: Islam, Asia Tenggara, peradaban 


\section{Pendahuluan}

Sedikitnya, dengan melihat jumlah pemeluk yang mencapai lebih dari seperempat milyar dan tersebar di beberapa negara seperti Indonesia, Malaysia, Singapura, Brunei Darussalam, dan ditambah komunitas Muslim di Filipina dan Thailand, Islam di kawasan Asia Tenggara secara potensial patut diperhitungkan sebagai salah satu kekuatan peradaban yang penting, selain kawasan Timur Tengah, Indo-Pakistan, dan beberapa kawasan penting lainnya. Dalam sebuah laporan yang dirilis oleh Pew Research Center's Forum on Religion \& Public Life pada Januari 2011 disebutkan bahwa dari 1,6 miliyar kaum Muslim di dunia, hampir 62,1\% di antara mereka tinggal di kawasan Asia Pasifik, 19,9\% tinggal Timur Tengah dan Afrika Utara, 15\% menempati wilayah Afrika sub-sahara, 2,7\% di Eropa, dan 0,3\% di Amerika. ${ }^{1}$ Dari data statistik tersebut dapat dilihat bahwa dua pertiga penduduk Muslim dunia tinggal di kawasan Asia Pasifik dan hanya seperlima saja yang menempati wilayah Timur Tengah dan Afrika Utara, yakni kawasan mayoritas penduduknya menggunakan bahasa Arab.

Populasi kaum Muslim diprediksi akan terus meningkat sampai 30\% pada 20 tahun ke depan, yakni pada tahun 2030. Tingkat pertumbuhan penduduk Muslim diperkirakan mencapai dua kali lipat dibandingkan non-Muslim, di mana rata-rata pertumbuhan Muslim pertahun berkisar 1,5\% sementara non-Muslim hanya berkisar 0,7\% pertahun. Prediksi pertumbuhan kaum Muslim ini didasarkan pada data time series, di mana pada tahun 1990 jumlah umat Islam mencapai 1,1 miliyar, tahun 2000 mencapai 1,3 miliyar dengan nilai pertumbuhan 19,9\%, tahun 2010 mencapai 1,6 miliyar dengan nilai pertumbuhan 21,6\%, tahun 2020 diprediksi mencapai 1,9 miliyar dengan nilai pertumbuhan 23,4\%, dan tahun 2030 diproyeksikan mencapai 2,2 miliyar dengan nilai pertumbuhan 24,9\%. ${ }^{2}$ Dengan kata lain, Islam menjadi agama yang memiliki perkembangan pemeluk terbanyak di dunia. Artinya, kaum Muslim akan mencapai 26,4\% dari total populasi penduduk bumi yang diproyeksikan mencapai 8,3 miliyar pada tahun 2030. Dengan kata lain, satu dari empat penduduk bumi adalah seorang Muslim.

Apabila dilihat berdasarkan sebaran kaum Muslim berdasarkan negara, ada empat negara yang memiliki jumlah populasi penduduk Muslim sangat besar, yakni Indonesia dengan jumlah penduduk Muslim mencapai 204.847.000, Pakistan berkisar 178.097.000, India berkisar 177.286.000, dan Bangladesh berkisar 148.607.000, yang kesemuanya merupakan negara yang berada di kawasan Asia. ${ }^{3}$ Di wilayah Asia Tengah, kaum Muslim terkonsentrasi di Kirgizstan, Uzbekistan, Tadjikistan, dan Turmenistan. Di kawasan Asia Selatan, mayoritas kaum Muslim tinggal di Afganistan, Pakistan, dan Bangladesh. Sementara di daerah Asia Tenggara, umat Muslim mayoritas berada di Indonesia, Malaysia, dan Brunei Darussalam.

${ }^{1}$ Pew Research Center's Forum on Religion \& Public Life, The Future of the Global Muslim Population Projections for 2010-2030, January 27, 2011.

${ }^{2}$ Ibid.

${ }^{3}$ Ibid. 
Namun demikian, ada juga sejumlah minoritas Muslim yang tinggal Khazakstan, India, Thailand, Filipina, Sri Lanka, Burma dan Singapura. ${ }^{4}$

Jika memperhatikan paparan data statistik di atas, maka membicarakan kontribusi Islam di kawasan Asia, teristimewa Asia Tenggara, tidak hanya penting untuk melihat perannya di masa lalu dan saat ini, tetapi juga perlu dilakukan untuk memprediksi kemungkinan kontribusinya bagi identitas peradaban di Asia Tenggara pada masa mendatang. Dengan mempertimbangkan corak ekspresi keberagamaan yang multikultural, akomodatif, toleran, dan berwajah damai, perlu juga diperhitungkan kemungkinan sumbangan positif Islam Asia Tenggara bagi pembentukan citra keislaman secara luas pada tataran global, mengingat posisi kawasan ini sebagai titik pertemuan segenap ekspresi budaya di dunia.

\section{Originalitas Islam Asia Tenggara}

Warna Islam Asia Tenggara yang sangat berbeda dengan warna Islam Timur Tengahsebagai kawasan tempat lahirnya Islam-sebenarnya telah menjadi perhatian sejumlah sarjana Barat. Bruce Vaughn misalnya, menganggap Islam Asia Tenggara terlihat memiliki karakteristik lebih moderat dibandingkan dengan Islam Timur Tengah. Sikap moderasi terasa menjadi nafas dalam kehidupan Islam Asia Tenggara. Menurutnya, hal ini bisa saja disebabkan karena Islam datang di wilayah ini melalui jalur perdagangan, bukan melalui jalur militer sebagaimana yang banyak terjadi di Asia Selatan dan Timur Tengah. Khusus di wilayah Indonesia, Islam juga telah mengalami proses dakwah kreatif dan strategi akulturasi, yang pada akhirnya memberikan kesan Islam di kawasan memiliki corak animisme, Hindu dan Buddha. ${ }^{5}$

Sejumlah sarjana lain juga menyimpulkan hal yang tidak terlalu berbeda. Menurut Mark Mancall, yang membuat wajah Islam Asia Tenggara berbeda dengan wajah Islam lain di belahan dunia adalah Islam Asia Tenggara tidak datang langsung dari Timur Tengah, namun melalui India. Dengan demikian, ajaran Islam yang diajarkan telah mengalami modifikasi dari hasil pengalaman Islam di India dan juga telah banyak dipengaruhi unsur sufisme. Tidak heran jika wajah Islam di kawasan ini nampak lebih lembut dan cenderung banyak mengandung unsur mistis, karena telah mengalami persinggungan dengan budaya HinduBuddha. Belum lagi secara historis, para pendakwah Islam di Indonesia-khususnya di pulau Jawa-merupakan para wali, yakni para tokoh sufi yang mengajarkan ajaran Islam dengan sangat santun dan toleran terhadap perbedaan. ${ }^{6}$ Pada awal 1950-an, Harry J. Benda juga telah mengatakan bahwa sejarah Islam Indonesia-sebagaimana juga yang ada di wilayah Asia Tenggara lain-pada hakikatnya adalah sejarah ekspansi kultural kaum santri. Perjalanan

${ }^{4}$ Bruce Vaughn, Islam in South and Southeast Asia, CRS Report for Congress Order Code RS21903 Updated February 8, 2005.

${ }^{5}$ Ibid.

${ }^{6}$ Azyumardi Azra, "From IAIN to UIN: Islamic Studies in Indonesia," dalam Islamic Studies and Islamic Education in Contemporary Southeast Asia (Malaysia: Yayasan Ilmu, 2001), h. 52-53. 
sejarah kaum santri telah memiliki dampak pada kehidupan keberagamaan dan politik di Indonesia. ${ }^{7}$

Islam Asia Tenggara, khususnya di Indonesia, bisa dikatakan mampu menjelma sebagai entitas keislaman baru. Di samping sebagai negara dengan penduduk Muslim terbanyak di dunia, tradisi Islam yang berkembang di Indonesia sangat khas dan unik. Bahkan hingga awal tahun 1980-an, Islam Indonesia dianggap berada di luar mainstream tradisi Islam. Menurut sejumlah sarjana, hal ini diakibatkan adanya fenomea sinkretisme dalam Islam Indonesia yang tidak akan dijumpai jika dikomparasikan dengan Islam Timur Tengah. ${ }^{8}$

Akan tetapi sangat disayangkan, Islam Indonesia, termasuk juga Islam Asia Tenggara secara umum, dibaca secara tidak proporsional oleh Anthony Reid. Reid menganggap fenomena Islam Indonesia sebagai Islam marginal—bukan Islam mainstream. Menurutnya, ini disebabkan oleh lambatnya Islam Indonesia dalam memasuki dunia Islam, sehingga tidak dapat membentuk dan mewarnai doktrin dan peradaban Islam secara umum. Ketika Muslim Indonesia mulai berinteraksi dengan komunitas Muslim dunia, ide tentang peradaban Islam telah lama mapan. Di samping, itu letak geografis Indonesia yang jauh dari wilayah komunitas Muslim Timur Tengah oleh Reid dianggap telah menjauhkan Muslim Indonesia dari problem sosial dan politik negara-negara Muslim lain. ${ }^{9}$

Namun demikian, argumentasi Reid banyak ditentang oleh sarjana lain. Sejumlah studi yang dilakukan oleh Roff (1985), Bulliet (1995), Keddie (1987), Ricklefs (1979; 1998), Hefner (1987), dan Woodward (1989) mematahkan semua argumentasi Reid. Tidak benar jika Islam Indonesia merupakan Islam periferal, baik secara keagamaan maupun intelektual, dibandingkan dengan Islam Timur Tengah. Islam Indonesia menjadi berbeda karena memang memiliki lingkungan sosial politik yang berbeda dan juga memiliki praktik dan interpretasi keagamaan yang unik pula. ${ }^{10}$ Fenomena tersebut justru harus dibaca terbalik bahwa para pemilikir Muslim di Asia Tenggara telah berhasil mengembangkan pemikiran yang berbeda. Tentu saja ini bukan sebuah upaya mudah. Kenyataannya, memang sedang berkembang sejumlah upaya di kalangan sarjana Muslim Asia Tenggara untuk memformulasi ide-ide yang secara substantif merespon pemikiran Islam, bahkan juga berbagai gagasan keislaman yang memiliki relevansi dengan kontek sejarah, sosiologi, budaya, dan politik Asia Tenggara. Hal ini sangat terlihat dalam beberapa konsep yang telah ditawarkan oleh para sarjana Muslim Asia Tenggara, sepertikonsep indigenisasi (indigenization) dan kontekstualisasi (contextualization) Islam Asia Tenggara. Upaya yang dilakukan berhasil membuat ekspresi keislaman di Asia Tenggara menjadi berbeda dengan yang ada di Timur Tengah dan dunia Islam lain. Pada

${ }^{7}$ Harry J. Benda, The Crescent and the Rising Sun: Indonesian Islam under the Japanese Occupation (The Hague \& Bandung: van Hoeve, 1958), h. 14.

${ }^{8}$ Azra, "From IAIN to UIN."

${ }^{9}$ Anthony Reid, Introduction in the Making of an Islamic Political Discourse in Southeast Asia (Clayton: Centre of Southeast Asian Studies, Monash University, 1993), h. 5.

${ }^{10}$ Azra, "From IAIN to UIN." 
tahun 1900-an misalnya, Islam Asia Tenggara dijuluki oleh media internasional terkemuka seperti Newsweek dan majalah Time sebagai Islam dengan 'Wajah Tersenyum' (Islam with a smiling face). Islam Asia Tenggara secara general telah dianggap sebagai merek damai (brand of peaceful) dan moderat yang tidak bermasalah dengan modernitas, demokrasi, hak asasi manusia, dan isu-isu lain di dunia modern. ${ }^{11}$ Hal inilah penting untuk terus dipromosikan kepada khalayak luas.

Dalam konteks ini, tatapan terhadap kontribusi Islam bagi penguatan citra peradaban yang ramah, toleran, inklusif, damai dan multikultural di Asia Tenggara mesti mempertimbangkan pula kebijakan masing-masing negara dalam memberikan ruang bagi penguatan Islam sebagai salah satu variabel penyumbang bagi terciptanya negara yang aman, damai, toleran, sejahtera, moderen, dan berkeadaban. Dengan mempertimbangkan adanya keragaman kebijakan yang diambil oleh masing-masing negara dalam memberikan pelayanan keagamaan secara keseluruhan, komunitas Islam di Asia Tenggara dapat secara bersama-sama membangun langkah-langkah strategis ke arah terbentuknya Islam sebagai salah satu kekuatan peradaban.

Hal lain yang tidak kalah pentingnya adalah fenomena semakin intensifnya kerjasama antar negara di kawasan Asia Tenggara dalam berbagai bidang kehidupan. Seperti dimaklumi bersama, kerjasama bilateral antar negara di kawasan ini mengalami perkembangan yang intensif dalam beberapa dekade terakhir. Berbagai kesepakatan kerjasama telah ditandatangani, baik dalam bidang ekonomi, industri, perdagangan, pendidikan, budaya, serta pertahanan dan keamanan regional, yang melibatkan tidak hanya pemerintah antarnegara, tetapi juga pengusaha dan kelompok civil society lainnya. Kerjasama yang semakin erat dan saling menguntungkan kedua pihak ini tentunya akan memberikan warna dan kontribusi yang semakin kuat bagi terciptanya kawasan Asia Tenggara sebagai salah satu pusat peradaban Muslim di dunia.

Selain itu, tampaknya juga penting dilakukan apresiasi secara sungguh-sungguh terhadap segenap khazanah intelektual, kultural, dan keagamaan yang ada sebagai titik tolak bagi usaha pengembangan dan penguatan citra keislaman yang ramah, toleran, moderen, dan berkeadaban di masa depan. Tentang hal ini, terdapat sederet tokoh penting yang telah ikut memberikan warna bagi corak keislaman di Asia Tenggara, seperti Syamsuddin Sumatrani, 'Abd Shamad al-Palimbani, Yusuf al-Maqassari, Nuruddin al-Raniry, Raja Ali Haji, dan Syaikh Nawawi al-Bantani. Dengan berbagai variabel lain yang dapat ditambahkan, masa depan komunitas Muslim Asia Tenggara diprediksi akan mengalami perkembangan yang semakin berarti dan diperhitungkan. Karena itu, mengedepankan wacana ini merupakan sesuatu yang penting dilakukan.

${ }^{11}$ Azyumardi Azra, "Islam in Southeast Asia: Tolerance and Radicalism," Paper Presented at Miegunyah Public Lecture The University of Melbourne, (Wednesday 6 April, 2005). 


\section{Urgensi Islam di Kawasan Asia Tenggara}

Sebagai salah satu identitas kultural yang penting dan dianut oleh mayoritas penduduk, komunitas Muslim di Asia Tenggara telah menapaki sejarah yang panjang dan berliku. Hal itu dimulai sejak kedatangannya pada sekitar abad ke-13 melalui usaha perdagangan dan dakwah para sufi, munculnya berbagai kerajaan dan kesultanan, hingga pada periode negara-bangsa (nation states) saat ini. Islam di Asia Tenggara menyimpan harapan masa depan yang cerah dan menggembirakan guna menjadi kiblat baru peradaban Islam. Optimisme ini sepenuhnya didasarkan atas sederet alasan yang sangat kuat, yakni:

Pertama, pada dua dasawarsa terakhir, Indonesia mengalami "panen raya" cendekiawan Muslim dalam berbagai bidang yang menamatkan studinya di berbagai negara, dan telah menghasilkan berbagai karya yang patut diperhitungkan secara akademis. Semua ini tentu merupakan perkembangan yang sangat signifikan bagi komunitas Muslim Asia Tenggara. Bisa dikatakan bahwa sejak tahun 1980-an, kelas menengah Muslim baru telah mengalami perkembangan. Kalau di Indonesia tidak ada terminologi khusus yang merepresentasi kelompok baru ini, berbeda dengan di Malaysia yang menyebut kelompok kelas menengah Muslim tersebut sebagai "new Malay."12

Kedua, tumbuhnya secara pesat kelas menengah Muslim yang bergerak di berbagai sektor ekonomi, bisnis, perbankan, dan sektor strategis lainnya, di samping kelompok yang berkhidmat di pemerintahan.

Ketiga, tumbuhnya perekonomian di kawasan Asia Tenggara secara signifikan dan menjadi salah satu kekuatan ekonomi dunia yang penting.

Keempat, kuatnya arus demokratisasi yang secara doktrinal memiliki relevansi yang kuat dengan nilai-nilai Islam.

Kelima, tumbuhnya secara pesat lembaga-lembaga keuangan syariah seperti perbankan, asuransi, Baitul Mal wat Tamwil, dan sebagainya. Perubahan arus politik pemerintahan di Indonesia dan Malaysia sejak tahun 1990-an yang lebih banyak mengakomodasi pendekatan konsiliasi antara ajaran Islam dan kelompok Muslim telah memberikan kontribusi terhadap munculnya sejumlah institusi keislaman baru, seperti bank Islam-yang lebih dikenal dengan bank syari'ah, sebuah institusi perbankan yang secara konsisten menerapkan hukum syari'ah, asuransi Islam (takaful), unit perkreditan rakyat Islam yang lebih dikenal dengan istilah bait al-mal wa al-tamwil (BMT). Pada waktu yang bersamaan juga berkembang sejumlah lembaga donasi keagamaan untuk zakat, infak, dan sedekah (ZIS) yang dikumpulkan dari orang yang berkecukupan untuk distribusikan kepada kelompok yang berhak. Munculnya fenomena lembaga keuangan syari'ah akhir-akhir ini, diharapkan kerjasama pemberdayaan ekonomi akan memperoleh momentumnya yang tepat. Goncangnya perekonomian Amerika

${ }^{12}$ Syed Hussein Alatas, The New Malay: His Role and Future (Singapore: Association of Muslim Professionals, 1996). 
yang merupakan salah satu kiblat perekonomian dunia juga memberikan kesempatan bagi munculnya sistem perekonomian syariah sebagai salah satu alternatif yang dapat dikembangkan, dalam rangka membentuk kerjasama ekonomi dalam lingkup regional di Asia Tenggara. Tentu saja ini tidak untuk dipahami sebagai penawaran sistem Islam secara eksklusif, tetapi lebih diarahkan pada kemungkinan terbentuknya zona ekonomi Asia Tenggara yang kokoh dan dapat terhindar dari berbagai guncangan ekonomi yang acapkali muncul.

Keenam, semakin tingginya gairah keagamaan sebagaimana diindikasikan oleh semaraknya tempat ibadah, semakin tingginya jumlah jamaah haji, dan tumbuh pesatnya penerbitan-penerbitan Islam. Sejumlah fenomena keislaman simbolik ini tidak bisa disangkal lagi. Telah berkembang beberapa tendensi baru dalam praktik keagamaan, institusi keislaman, gaya hidup Islam yang diadopsi oleh sejumlah kelompok Muslim. Banyak masjid didirikan dengan corak arsitektur Timur Tengah yang diramaikan berbagai kegiatan spiritual yang banyak dihadiri kaum muda. Pada sisi lain, semangat untuk menunaikan ibadah haji maupun umrah ke Tanah Suci Makkah di kalangan kaum Muslim juga tumbuh pesat. Menurut data yang ada, angka jamaah haji dari Asia Tenggara mencapai 225.000 orang per tahun. Jumlah ini masih jauh lebih banyak jika dibandingkan jumlah jamaah haji dari kawasan Muslim lain di dunia.

Ketujuh, adanya kesamaan kultur kemelayuan yang memperkokoh corak keislaman Sunni, sehingga dapat mempererat kerjasama budaya antarbangsa di Asia Tenggara. Secara umum, kaum Sunni memang menjadi kelompok mayoritas Muslim dunia. Hanya sekitar $10-15 \%$ saja yang menganut paham Syi'ah. Perbedaan paham keagamaan ini lebih dipicu karena tidak adanya kesepakatan tentang pimpinan pasca Rasulullah SAW. Di kawasan Asia Selatan dan Asia Tenggara, populasi kaum Syiłah hanya signifikan jumlahnya di Afganistan dan Pakistan. ${ }^{13}$ Adanya kesamaan corak keislaman ini tentu menjadi asset yang sangat berharga untuk upaya membangun peradaban baru Islam Asia Tenggara.

Tentu saja berbagai kekuatan dan peluang yang masih dapat ditambahkan ini menjadi modal dasar yang penting dalam membangun langkah bersama, baik antar pemerintah, maupun antar lembaga sosial keagamaan dan lembaga pendidikan yang ada di kawasan ini bagi terwujudnya kekuatan baru Islam di Asia Tenggara. Tetapi, sesuai dengan wataknya yang toleran dan inklusif, peradaban baru Islam di Asia Tenggara ini mesti dibangun bersamasama komunitas lain di atas semangat saling menghormati, saling mengayomi, saling menghargai, dan saling membantu di atas landasan kemanusiaan universal dan hubungan persaudaraan antarbangsa di sekitar kawasan.

Disadari sepenuhnya, bahwa kawasan ini dibangun secara bersama-sama dengan komunitas keagamaan lain yang kontribusinya sangat penting dan signifikan. Kesediaan bangsa Indonesia untuk hidup bersama dan berdampingan dalam rangka membangun bangsa

${ }^{13}$ C. Mark, Islam: A Primer, CRS Report RS21432. Lihat juga F. Armanios, Islam: Sunnis an Shiites, CRS Report RS21745; F. Armanios, The Islamic Traditions of Wahhabism and Salafiyya, CRS Report RS21695. 
sepenuhnya memiliki landasan keagamaan yang kuat dalam Islam. Bahwa dalam sumber ajarannya yang paling penting, yakni al-Qur'an, Islam memandang perbedaan keyakinan dan pluralitas pemahaman keagamaan sebagai sesuatu yang sah, alami (sunnah Allâh) dan manusiawi. Karena itu, sepenuhnya disadari bahwa membangun peradaban Islam di Asia Tenggara berarti sama dengan membangun masa depan kawasan bersama seluruh komponen dan kekuatan bangsa-bangsa serta pelbagai komunitas yang ada di dalamnya.

Tetapi, sebagai kekuatan terbesar pemeluk agama, komunitas Muslim merupakan kunci utama bagi terbangunnya peradaban Asia Tenggara yang inklusif, toleran, multikultural, dan modern di masa depan. Tanpa semangat kultural seperti ini, bukan hanya Asia Tenggara sebagai pusat peradaban Islam tidak akan terwujud, tetapi juga seluruh prasyarat yang diperlukan bagi terciptanya keamanan dan stabilitas bangsa akan hancur. Sesuai dengan etos kemelayuan yang terbuka, dinamis, dan pluralistik, maka citra Islam di Asia Tenggara sepenuhnya berseberangan dengan asumsi sebagian pihak yang memandang Islam sebagai ajaran yang eksklusif, statis, monolitik, literal, skriptural, dan bernuansa teror. Karenanya, munculnya gerakan-gerakan keagamaan akhir-akhir ini yang melakukan langkah-langkah destruktif harus dipandang sebagai paham yang menyimpang dari-dan bertentangan dengannilai dasar Islam yang sesungguhnya. Inilah yang disinyalir Howard Federspiel sekitar dua sekade silam, bahwa sejak empat ratusan tahun, Indonesia-dan juga Islam di kawasan Asia Tenggara secara umum - menampilkan keyakinan dan praktik keagamaan yang bercorak heterodoks, yang dewasa ini secara perlahan namun pasti mulai bergeser ke corak ortodoks. ${ }^{14}$

Lahirnya paham keagamaan ortodoks dalam Islam, tidak terkecuali yang berkembang di Asia Tenggara, menurut Vartan Gregorian tidak lepas dari faktor kemunduran supremasi Islam yang diakibatkan oleh ekspansi kolonial Eropa. Dari sinilah muncul dua mazhab pemikiran dalam Islam yang sampai sekarang bisa dikatakan masih sangat relevan, yakni kelompok tradisionalis dan reformis. Kelompok tradisionalis percaya bahwa sebab kemunduran Islam dapat ditelusuri pada kelematan moral (moral laxity) dan penyimpangan jari ajaran Islam yang benar. Konsekuensinya, respon yang dimunculkan kelompok ini adalah ajakan untuk kebangkitan Islam (Islamic revival). Sementara mazhab yang lain, yang lebih dikenal dengan mazhab reformis, merasa bahwa kemunduran Islam lebih diakibatkan kegagalan kronis untuk memodernisasi masyarakat dan institusi Islam. Kelompok sempalan dari mazhab ini telah mencoba untuk mengajukan pertanyaan kritis mengenai kemungkinan untuk memodernisasi masyarakat dan institusi Muslim tanpa melakukan westernisasi. Bagaimana kiat untuk memproteksi warisan budaya masyarakat dan praktik tradisional di era global dan bagaimana mengembangkan eksistensi bersama antara modernisasi dan tradisionalisasi tanpa westernisasi. ${ }^{15}$

\footnotetext{
${ }^{14}$ Howard M. Federspiel, Persatuan Islam: Islamic Reform in Twentieth Century Indonesia (Ithaca, NY: Cornell University Modern Indonesia Project, 1970), h. 3.

${ }^{15}$ Vartan Gregorian, Islam: A Mosaic Not a Monolith (Washington: Brookings Institute, 2003), h. 50.
} 
Adanya mazhab pemikiran seperti disebutkan di atas, tentu menjadi salah satu hambatan nyata untuk mewujudkan peradaban Islam Asia Tenggara sebagai kiblat peradaban Islam baru. Sebagai kekuatan mayoritas di Asia Tenggara, sikap dasar komunitas Muslim sepenuhnya harus bersifat menghormati, mengayomi dan melindungi, serta memberikan iklim yang kondusif bagi kelompok keagamaan lain untuk mengekspresikan nilai dan budayanya secara terbuka. Hal ini didasarkan atas adanya kenyataan bahwa segenap komponen agama dan budaya pada dasarnya memiliki semangat dan nilai yang sama, yakni perdamaian, persamaan, keadilan, keterbukaan, dan terwujudnya cita-cita kemanusiaan universal bagi seluruh bangsa.

Dalam pada itu, mengaitkan identitas keislaman dengan kultur kemelayuan di Asia Tenggara merupakan suatu keniscayaan yang tidak terbantahkan. Secara doktrinal, tidak ada alasan untuk menolak dan menegasikan kemungkinan munculnya berbagai corak ekspresi keagamaan yang memang beraneka ragam. Dalam bukunya yang terkenal, tsaqafâtuna bain al-infitah wa al-inghilaq (Peradaban Islam antara Inklusifisme dan Eksklusifisme), Yûsuf Qaradhâwî secara tegas menyebut "keberbagaian" (tanawwu') ini sebagai salah satu ciri utama dan watak dasar peradaban Islam. Sementara secara sosiologis dan historis, keberbagaian atau pluralitas ini muncul akibat adanya persentuhan Islam dengan pelbagai lokalitas budaya yang memang beragam. Maka, pada titik inilah dapat dipahami secara utuh tentang pentingnya adat atau tradisi ('adat al muhakkamah) sebagai salah satu sumber hukum. Karena itu, adanya perbedaan ekspresi kultural keislaman di Asia Tenggara dibandingkan dengan pusat-pusat peradaban Islam di wilayah lain seperti Arab Saudi, Mesir, Indo-Pakistan, dan Iran tidak harus dipahami sebagai fenomena Islam periferal atau pinggiran yang menyimpang dan tidak murni, tetapi mesti dipandang sebagai corak kultural Islam alternatif yang dapat mengambil peran dan posisi yang penting di masa depan.

Kurang lebih, dalam corak ekspresi keberagamaan Islam yang multikultural, akomodatif, toleran, dan berwajah damai inilah, dapat digagas tentang Asia Tenggara sebagai salah satu pusat peradaban Islam di dunia. Dengan mempertimbangkan berbagai kekuatan dan potensi yang tersedia saat ini, rasanya bukan hal yang berlebihan apabila digagas kemungkinan munculnya kiblat baru peradaban Islam di Asia Tenggara.

\section{Ke Arah Masa Depan Peradaban Islam di Asia Tenggara}

Seiring dengan semakin kuatnya semarak keislaman di Asia Tenggara, patut optimis bahwa komunitas Muslim di kawasan ini akan tampil sebagai salah satu kekuatan budaya yang penting dan diperhitungkan. Optimisme ini tentunya perlu ditindaklanjuti dengan berbagai langkah kongkret, meliputi peningkatan kerjasama pemberdayaan ekonomi umat, penguatan kerjasama pendidikan, penguatan kerjasama lembaga-lembaga sosial keagamaan, kerjasama penelitian dan pengembangan, serta penerbitan karya-karya akademis, pengarusutamaan corak keislaman yang inklusif, toleran, ramah, dan damai, serta berbagai bentuk kerjasama program lainnya. 
Sebagai kelompok negara-negara yang termasuk ke dalam kategori "Dunia Ketiga," salah satu problem utama umat Islam saat ini adalah masih tingginya angka kemiskinan dan rendahnya akses sebagian umat terhadap sumber daya ekonomi. Hal ini disebabkan oleh berbagai faktor seperti rendahnya tingkat pendidikan dan kualifikasi keilmuan, terbatasnya penguasaan teknologi, dan terbatasnya modal. Karena itu, kerjasama pemberdayaan umat perlu mendapat perhatian serius dari semua pihak. Setidaknya untuk kasus Indonesia, masalah pemberdayaan ekonomi mesti memeroleh perhatian yang lebih serius terkait dengan masih tingginya lulusan madrasah (Tsanawiyah dan Aliyah, bahkan juga STAIN, IAIN, dan UIN, serta mahasiswa perguruan tinggi Islam lainnya dan pondok pesantren) yang belum memperoleh akses yang memadai dalam bidang ekonomi. Hal ini penting, karena salah satu cara yang paling efektif untuk melakukan transformasi kelas sosial—yang lebih sering diidentikkan dengan kelas ekonomi—bagi kelompok masyarakat tertentu adalah melalui jalur pendidikan. Karena itu, akses terhadap pendidikan yang berkualitas menjadi kunci utama dalam proses pembangunan secara makro dan untuk pemberdayaan masing-masing individu dalam skala mikro.

Dalam konteks ini, Indonesia sudah cukup lama konsen terhadap pendidikan Islam yang berkualitas bagi masyarakatnya, baik pendidikan yang diselenggarakan oleh pemerintah maupun masyarakat. Untuk level perguruan tinggi Islam yang diselenggarakan pemerintah misalnya, pemerintah melalui Kementerian Agama telah menyelenggarakan tidak kurang dari enam Universitas Islam Negeri (UIN), 15 Institut Agama Islam Negeri (IAIN)—yang telah didirikan sejak tahun 1960-an, dan 31 Sekolah Tinggi Agama Islam Negeri (STAIN). Khusus untuk UIN, pemerintah telah memberikan wider mandate bagi institusi pendidikan tinggi tersebut tidak hanya menyelenggarakan program studi studi-studi Islam, namun juga telah mengembangkan bidang kajian program studi ilmu-ilmu sains dan teknologi. Tentu saja proses pendidikan yang diupayakan melalui berbagai institusi pendidikan Islam, baik perguruan tinggi maupun lembaga pendidikan lain, tanpa diragukan lagi akan memainkan peran penting dalam proses modernisasi masyarakat Muslim. Terbukti, sejumlah alumni lembaga pendidikan ini memiliki pemikiran Islam yang progresif, inklusif dan toleran.

Selain itu, dalam rangka penguatan kualitas sumber daya manusia Muslim Asia Tenggara, perlu juga diperkokoh kerjasama dalam bidang pendidikan. Sebagai modal sosial yang paling penting dan utama bagi penguatan kontribusi Islam terhadap wajah peradaban di Asia Tenggara, perhatian terhadap kerjasama pendidikan perlu diperkuat dan diperluas dalam berbagai bentuk, seperti penguatan manajemen kelembagaan, pengembangan desain pembelajaran, penyediaan bahan pustaka, pengembangan teknologi pendidikan, peningkatan kualitas tenaga dan guru/dosen, pengembangan model, pertukaran siswa dan mahasiswa, serta pelbagai kerjasama pendidikan lainnya. Kerjasama ini tidak hanya dimaksudkan bagi pemerataan akses pendidikan kepada segenap lapisan masyarakat, tetapi juga diharapkan dapat terbangun sumber daya manusia Muslim yang semakin berkualitas dan mampu bersaing pada tataran global. Adanya, fenomena "panen raya" intelektual Muslim dalam dua dekade terakhir ini diharapkan dapat diperkuat dalam bentuk penguasaan akses terhadap berbagai bidang usaha dan lembaga ekonomi bagi pemberdayaan dan kesejahteraan umat. 
Namun ada pula aspek yang tidak boleh diabaikan begitu saja dalam upaya membangun peradaban Islam Asia Tenggara yang diproyeksikan sebagai kiblat baru peradaban Islam dunia. Geliat gerakan Islam radikal yang muncul di kawasan Asia Tenggara harus mendapatkan perhatian ekstra serius dari semua pihak. Sekarang inilah waktu yang tepat untuk para sarjana, pemimpin, dan seluruh elemen Muslim Asia Tenggara untuk terus mengembangkan ajaran Islam yang moderat sebagai pembanding atas gerakan radikalisme Islam. Seluruh elemen kaum Muslim berkewajiban untuk menyosialisasikan Islam Asia Tenggara sebagai Islam moderat, Islam yang cinta damai, dan Islam yang rahmmat li al-'âlamîn.

Problem radikalisme yang muncul dalam Islam setidaknya dapat dilihat dari dua sisi. Pertama, distorsi pemahaman terhadap doktrin Islam untuk menjustifikasi paham radikalisme dan terorisme. Kedua, maraknya praktik kekerasan yang tidak dapat disangka berkembang di sejumlah negara Muslim_yang sebenarnya sebagai respon atas kondisi sosial politik di masing-masing kawasan. Di sinilah diperlukan upaya komunikasi, informasi, dan edukasi bagi publik bahwa praktik rasikalisme dalam Islam merupakan sebuah distorsi pemahaman keagamaan.

Selain melalui jalur pendidikan yang diselenggarakan melalui institusi pendidikan, upaya sosialisasi dan edukasi tentang Islam moderat menjadi sangat efektif jika dilakukan melalui media. Upaya yang telah dilakukan Kementerian Agama yang bekerjasama dengan The Muslim World League pada Konferensi Internasional Media Islam pada bulan Desember 2011 yang dilaksanakan di Jakarta merupakan tonggak sejarah baru bagi Islam Asia Tenggara. Dalam konferensi tersebut, Indonesia telah ditunjuk oleh peserta konferensi sebagai follow up commite untuk menyelenggarakan sejumlah agenda yang dapat memperkuat posisi media Islam. Kesempatan ini benar-benar harus dimanfaatkan, karena sebagai negara dengan umat Muslim terbesar sudah selayaknya Indonesia memimpin dan memberikan warna bagi masa depan Islam untuk kepentingan umat secara luas.

Agar bisa melakukan fungsi sosialisasi dan edukasi secara maksimal, posisi media harus diperkuat. Media di negara-negara Muslim sekarang harus diakui dengan jujur masih sangat lemah. Konten pemberitaan media di negara-negara Muslim, terutama di kawasan Asia Tenggara, belum ada yang fokus untuk pemberitaan Islam yang moderat dan Islam yang rahmat lial-ấlamîn. Fakta di lapangan menunjukkan bahwa arah dan orientasi pemberitaan media masih dikuasai the big three yang itu nota bene dikuasai Barat. Ini menjadi persoalan serius bagi upaya pembangunan kiblat baru peradaban Islam di kawasan Asia Tenggara. Karena dengan demikian, arah pemberitaan akan terus dikendalikan dan ditentukan oleh tiga besar pemilik agen media internasional tersebut. Sehingga tidak heran jika pemberitaan Islam yang muncul di tengah-tengah masyarakat masih didominasi dengan wajah Islam yang sangat bertentangan dengan spirit Islam yang sesungguhnya, yakni Islam yang cinta damai, yang lebih dekat dengan representasi wajah Islam di kawasan Asia Tenggara. Tentu saja harus ada upaya untuk mengakhiri fenomena ini, di antaranya dengan cara memperkuat peran media di negara-negara Muslim. Karena dengan cara itulah dapat diciptakan keseimbangan 
informasi di dunia baru. Tujuannya tidak lain agar suara Muslim, terutama Muslim Asia tenggara, bisa dipahami dengan baik, di mana selama ini Islam paling sering disalahpahami oleh banyak kalangan.

Sejumlah agenda strategis untuk menanggulangi problem ini telah dirancang, diantaranya adalah rencana untuk menyelenggarakan sebuah forum yang memberikan ruang dialog para insan media, termasuk wartawan Barat yang selama ini telah banyak salah paham tentang Islam. Mereka perlu diberi informasi yang jelas tentang bagaimana demokrasi maupun toleransi telah berjalan baik di Indonesia. Dengan berperan sebagai follow up commite pada Konferensi Internasional Media Islam, Indonesia sangat berpeluang menjadi figur baru dalam proses komunikasi, informasi, dan edukasi Islam Asia Tenggara yang moderat dan cinta damai. Melalui berbagai upaya strategis seperti inilah, baik melalui proses edukasi formal maupun informal, protes Islam yang sebenarnya dapat disosialisasikan secara maksimal kepada publik.

\section{Penutup}

Pada akhirnya, munculnya harapan Asia Tenggara sebagai salah satu pusat peradaban dunia Islam kiranya bukan sebagai utopia atau mimpi di siang hari belaka. Tetapi akan menjadi kenyataan sepanjang umat Islam mampu secara sungguh-sungguh menggali berbagai potensi yang dimiliki. Tulisan ini tentu belum dan tidak dapat menggambarkan detail kontribusi Islam terhadap peradaban modern di Asia Tenggara. Tetapi setidaknya tulisan ini dapat menjadi pengantar diskusi, stimulasi lahirnya gagasan, dan ide-ide cerdas dalam merumuskan strategi pengembangan peradaban Islam di Asia Tenggara ke depan.

\section{Pustaka Acuan}

Alatas, Syed Hussein. The New Malay: His Role and Future. Singapore: Association of Muslim Professionals, 1996.

Armanios, F. Islam: Sunnis an Shiites. CRS Report RS21745.

Armanios, F. The Islamic Traditions of Wahhabism and Salafiyya. CRS Report RS21695.

Armstrong, Karen. Islam: A Short History. New York: The Modern Library, 2002.

Azra, Azyumardi. "From IAIN to UIN: Islamic Studies in Indonesia," dalam Islamic Studies and Islamic Education in Contemporary Southeast Asia. Malaysia: Yayasan Ilmu, 2001.

Azra, Azyumardi. "Islam in Southeast Asia: Tolerance and Radicalism," Paper Presented at Miegunyah Public Lecture the University of Melbourne, Wednesday 6 April, 2005.

Benda, Harry J. The Crescent and the Rising Sun: Indonesian Islam under the Japanese Occupation. The Hague \& Bandung: van Hoeve, 1958.

Federspiel, Howard M. Persatuan Islam: Islamic Reform in Twentieth Century Indonesia. Ithaca, NY: Cornell University Modern Indonesia Project, 1970. 
MIQOT Vol. XXXVI No. 1 Januari-Juni 2012

Gregorian, Vartan. Islam: A Mosaic Not a Monolith. Washington: Brookings Institute, 2003.

Hefner, Robert. Islam and Asian Security: Strategic Asia. T.t.t.: t.p., 2003.

Mark, C. Islam: A Primer. CRS Report RS21432.

Pew Research Center's Forum on Religion \& Public Life, The Future of the Global Muslim Population Projections for 2010-2030, January 27, 2011.

Rabasa, Angel. Political Islam in Southeast Asia: Moderates, Radicals and Terrorists. Adelphi: International Institute for Strategic Studies, 2003.

Reid, Anthony. Southeast Asia in the Age of Commerce, 1450-1680. New Haven \& London: Yale University Press; 1993.

Reid, Anthony. Introduction: In The Making of an Islamic Political Discourse in Southeast Asia. Clayton: Centre of Southeast Asian Studies, Monash University, 1993.

Vaughn, Bruce. Islam in South and Southeast Asia. CRS Report for Congress Order Code RS21903. 